\title{
Public Participation in Post-Fordist Urban Green Space Governance: The Case of Community Gardens in Berlin*
}

\author{
Participación pública en la gobernanza posfordista de espacios \\ verdes urbanos: el caso de los huertos comunitarios en Berlín
}

\author{
Marit Rosol $^{* *}$ \\ Hábitat y sociedad (ISSN 2173-125X), n. ${ }^{\circ}$ 7, noviembre de 2014, pp. 15-30.
}

\begin{abstract}
Summary
This article examines citizen participation in the governance of contemporary urban green space. Rather than exploring normative questions of ideal forms of participatory democracy, it focuses on changing roles and relationships between local state and non-state actors in order to identify and explain the changing nature of participation. I argue that neoliberal urban restructuring has changed the conditions for participation and thus participation itself in fundamental ways and that we need an account of changes in statehood and governance in order to capture this conceptually. Based on the case of community gardens in Berlin, the article discusses the extent to which this changed relationship is expressed by current citizen participation as well as the potential and problems that result from it. My empirical results show the emergence of a new political acceptance of autonomously organized projects and active citizen participation in urban green space governance. The central argument of this article is that this new acceptance can be conceptualized as an expression of the neoliberalization of cities. Nevertheless, this neoliberal strategy at the same time leads to complex and contradictory outcomes and the resulting benefits are also acknowledged.
\end{abstract}

\section{Key words}

Community garden, public participation, post-fordist cities, neoliberal urban policies

\begin{abstract}
Resumen
Este artículo analiza la participación ciudadana en la gestión pública de espacios verdes urbanos contemporáneos. Más que explorar las cuestiones normativas de formas ideales de democracia participativa, el artículo se centra en el cambio de roles y relaciones entre el Gobierno local y los actores no gubernamentales con la finalidad de identificar y explicar la naturaleza cambiante de la participación. Argumento que la reestructuración urbana neoliberal ha cambiando las condiciones de participación, y por tanto la participación en sí misma, de forma fundamental y por ello necesitamos un registro de los cambios en el Gobierno y la condición del Estado para captar este cambio en la participación conceptualmente. Basándose en el caso de los huertos comunitarios de Berlín, el artículo discute sobre en qué medida la participación ciudadana actual refleja este cambio de relaciones así como los problemas y las potencialidades que resultan del mismo. Mis resultados empíricos muestran la emergencia de una nueva aceptación política de proyectos organizados de forma autónoma y de la participación ciudadana activa en la gestión de espacios verdes urbanos. El argumento central de este artículo es que esta nueva aceptación puede ser conceptualizada como una expresión del avance neoliberal en las ciudades. Sin embargo, esta estrategia neoliberal conduce a resultados complejos y contradictorios a la vez que los beneficios resultantes son también reconocidos.
\end{abstract}

\section{Palabras clave}

Huertos comunitarios, participación ciudadana, ciudades posfordistas, políticas urbanas neoliberales

\footnotetext{
* El artículo es una reedición de: Rosol, Marit (2010): Public participation in post-Fordist urban green space governance: The case of community gardens in Berlin. International Journal of Urban and Regional Research 34, 548-563. By permission of John Wiley and Sons. ** Profesora del Departamento de Geografía Humana de la Universidad de Frankfurt, Alemania. Doctora por el Instituto Geográfico de la Universidad Humboldt. C.e.: rosol@geo.uni-frankfurt.de. Web: http://www.uni-frankfurt.de
} 


\section{Introduction}

This article examines the role of citizen participation in contemporary urban green space governance. Rather than exploring normative questions of ideal forms of participatory democracy (Silver et al., 2010, this issue), it focuses on changing roles and relationships between local state and non-state actors in order to identify and explain the changing nature of participation. Based on literature inspired by regulation theory, the article situates citizen participation in the context of "actually existing neo-liberalism" (Brenner and Theodore, 2002a). The starting point of the article is an understanding of the process of neoliberalizing cities, that not only entails entrepreneurial strategies, but in which also civic engagement gains importance as a substitute for welfarist functions of the local state. Based on a literature review and an empirical case, I argue that neoliberal urban restructuring has changed the conditions for participation and thus participation itself in fundamental ways, and that we need an account of changes in statehood in order to capture this conceptually. These developments lead to ambivalent outcomes, which the article also aims to explore.

The article is organized as follows. I first summarize core arguments from the literature on the neoliberalization of cities and the effect it has had on participation. Secondly, I present my empirical case study on community gardens in Berlin. Thirdly, I summarize these empirical cases concerning the changing roles and aims of the local state. Finally, I conclude by discussing the case in the context of neoliberal urban restructuring and the specific Berlin situation.

\section{Citizen participation in neoliberalizing cities}

The term 'neoliberalizing cities' refers here to work inspired by regulation theory that focuses on the implementation since the 1980s of neoliberal ideology through urban policy (e.g. Painter and Goodwin, 2000; Brenner and Theodore, 2002b; 2005; Jessop, 2002; Peck and Tickell, 2002). Three observations are crucial for my argument here:

Firstly, there has been a shift in planning paradigms towards competition and a new understanding of cities as entrepreneurs and enterprises (Harvey, 1989; Hall and Hubbard, 1998). Urban development policies are now primarily directed towards business development and less towards the provision of collective services, which used to be the traditional core-task of the local state (Mayer, 1994). Public parks, as a part of urban collective infrastructures in the city, are affected by this reorientation of urban policies.

Secondly, new forms of governance-beyond-the-state have emerged from the transformation of the welfare state towards the activating state (for a critique cf. Esser, 1998; Lindenberg, 2002; Swyngedouw, 2005). This has led to an increasing importance of non-state actors and to a transformation of roles, responsibilities and institutional configurations of the (local) state and citizens in urban spatial politics.

Lastly, this development goes hand in hand with the rising importance of civic engagement and a new focus on territorially defined local communities as a relevant actor in urban governance. Neo-communitarians in particular advocate that civic societyand community are the opposite and alternative to market-led and competition-oriented 
neoliberal politics (Etzioni, 1993). On the other hand, critical research suggests that voluntary engagement within the community fulfils the role of compensating for the state's retreat from its former welfarist functions (Evers, 2002; Mayer, 2003; Roth, 2003; Amin, 2005) and for the worst consequences of "pure" neoliberal —or neoclassical- strategies such as deregulation and privatization. Jessop (2002: 108) identifies the rise of a new political ethos that "tends to promote 'community' (or a plurality of self- organizing communities) as a flanking, compensatory mechanism for the inadequacies of this market mechanism".

However, community-based and controlled services do not seem to be the only or even primary answer to neoliberal restructuring. Instead, they address the longstanding left-wing critique of the Fordist welfare state. On the one hand, the specific forms and institutions of social welfare were criticized. In particular, the criticism of the bureaucratic, mechanized and incapacitating health service led to a massive explosion of self-help groups in the 1970s and 1980s which were at that time by no means accepted by the all-embracing, protecting and controlling state. Collective self-helpwas contested, clients should remain inactive, participation needed to be won (among many others, see Thiel, 1994 for the German context). On the other hand, the criticism addressed the repressive function of the state. Beside the protection against material risks (illness, age, unemployment, etc.), the task of the welfare state has also been the regulation of the labour supply through discrimination, privileges, discipline and control. Extension and perfection of the social state were closely associated with an expansion of the control of its citizens, with the cooperation of the education system, police, justice, working and social management (see e.g. Hirsch, 1982; Krätke and Schmoll, 1987: 64ff.; Rose, 1996: 330).

As a result, the Keynesian welfare state came under attack by neoliberal as well as left-wing critics. The situation today is therefore a product of those critiques, but also an ongoing incorporation of left-wing critique and language into neoliberal policy. Regarding urban policy, thus not only is entrepreneurialism encouraged on the local level, but so are new forms of social cohesion and community participation (Jessop, 2001; Brenner and Theodore, 2002a). Theoretical as well as empirical research (e.g. Elwood, 2002; Ghose, 2005; Herbert, 2005; Geddes, 2006) has shown how neoliberal urban governance has shaped citizen participation on the local scale in the following five respects:

1. A growing responsibility of citizens and civic institutions corresponding to the neoliberal goal of greater institutional efficiency, which is usually not accompanied by increasing resources, influence and power (Ghose, 2005).

2. The outsourcing and privatization of state services towards the profit-making and the non-profit sector and to volunteering citizens (Bondi and Laurie, 2005).

3. The emergence of a discourse of collaboration that "has the potential to depoliticise urban governance practices and effectively discipline community organizations into forms of participation that are more manageable for the state" (Elwood, 2002: 123).

4. The co-optation of energy, time and agendas of participating citizens (Elwood, 2002).

5. Increased competitiveness among community-groups -e.g. as they compete for grant funding - at the expense of cooperation (see e.g. MacKinnon, 2000: 298). 
These general trends are path-dependent and recent research on neoliberal urban transformations acknowledges the "uneven, contentious, volatile and uncertain character" (Brenner and Theodore, 2005: 101) of these restructuring processes. Participatory processes and the downloading of responsibility onto community groups can lead to complex and contradictory outcomes - it may serve a neoliberal agenda, but at the same time still foster an emancipatory agenda. This points to the high spatial variability of these outcomes (Elwood, 2002; 2004), which, therefore, will also be further explored in this article.

In providing an analysis of participation in urban governance "on the ground" and over time, this article moreover seeks to overcome a binary opposition present in theoretical discussion on participatory democracy (for a discussion see Silver et al., this issue) and rather tries to show how bottom-up and top-down approaches as well as consensus and confrontation, and making use of direct and representative forms of democracy, are all present in the strategies of parties involved. However, this article is also in agreement with Aylett (2010, this issue) and Becher (2010, this issue) in their emphasis on conflict and clashes of interest as positive elements that are ever present in these processes -i.e. also in deliberation - as they are in a capitalist society in general. I argue that the shape and outcome of participatory processes are hardly determined by an imaginary "perfect" participatory models or tools, by deliberation and the "power of the better argument", nor indeed by the "perfect" protest strategy, but rather by the real-existing balance of forces, by (mostly mundane) struggles, and by the historically and geographically specific circumstances and conditions of these struggles.

Based on the above literature review, the article will now turn to the case study on community gardens in Berlin. It will focus on the first two observations concerning participation and neoliberal urban governance, thus referring to the changing role of state and non-state actors in urban green space governance by addressing the following questions:

1. To what extent are the changing conditions for citizen participation expressed in the changing role of state and non-state actors?

2. What are the potentials and limits of citizen participation in the context of neoliberal restructuring of urban governance?

\section{Urban green space governance in Berlin}

As a result of the leftist critique of the paternalistic welfare state described above, the 1970s saw the formation of New Social Movements (for the German context, see Brand et al., 1986) and Bürgerinitiativen (citizens'actions committees) concerned with municipal policies and the urban environment (see Roth, 1994 among others). For example, radical protest and self-help was expressed in the squatting movement of the early 1980s in West Berlin (Bodenschatz et al., 1983). As part of

1. In East Berlin at the same time, people were involved in environmental initiatives ranging from officially accepted conservationist groups to alternative and persecuted groups like the Berlin Umweltbibliothek (Environmental Library) (Rüddenklau, 1992). Because of the highly different political and social context in the GDR, these examples cannot be classified equally as part of NSM as in the West. the environmental movement people also protested "against the administrative control of urban greenery" (Meissle, 1998: 248, translation by author) by starting to green patios and backyards of tenement housing blocks, lobbying for more urban green spaces and even publicly squatting in existing open spaces to protect them from development. ${ }^{1}$ A look at urban green space governance in Berlin today reveals entrepreneurial strategies as well as the call for more civic engagement. The 
severe cuts in public funding for public green space, due to a severe fiscal crisis of the City of Berlin (Krätke, 2004), led to a search for new ways of maintaining parks, playgrounds and other public green spaces. The City of Berlin adopted entrepreneurial strategies like the formal privatization of parks, the introduction of park entrance fees, the increased use of the low-wage sector and workfare programs for maintenance and the outsourcing of maintenance work to private companies. At the same time - and of particular importance to this article- local politicians have specifically called for civic engagement as a form of citizen participation (EA. UE, 2000; Schröder, 2000; Krug-Gbur and Preisler-Holl, 2004). For example, in 2004 one borough (Bezirk) started an initiative for the "rescue of the borough parks" (slogan of the campaign), in which local residents were encouraged to adopt their parks. Another campaign from a different borough also asked for volunteers to support the parks department. In both cases the calls for civic engagement were justified with the lack of funding for public green spaces. ${ }^{2}$ Although the current situation in Berlin is influenced both by leftwing as well as neoliberal critique of the welfare state, I will argue that the increasing interest of the City of Berlin in civic engagement has to be related mainly to a new, neoliberal model of the state. This model changed from Fordist welfare and the Sicherheitsstaat (security state) (Hirsch, 1980) to an "activating and enabling state" (see above), particularly expressed by the 'Red-Green' government in power from 1998 to $2005 .^{3}$

\section{Community gardening in Berlin}

Here I will look at a specific example of civic engagement: community gardens. I chose community gardens as a case study because firstly the engagement expressed here is a form of a long-term commitment (as opposed to day-long neighbourhood clean-ups for example), and secondly the way such a garden is run is to a large extent self-determined. That means that the case of community gardens is especially complex for the study of neoliberalism because it is not pure outsourcing of maintenance work, but is profoundly defined by grassroots characteristics. ${ }^{4}$ I define community gardens as public green spaces run by volunteers. They have to be distinguished from the well-known private- German allotment gardens (Schrebergärten). Community gardens have no widely acknowledged common definition. Nevertheless, we can find community gardens or forms of collective urban agriculture worldwide (Mathéy, 2000; Meyer-Renschhausen, 2002; Baker, 2004; Haidle and Arndt, 2007). Most of these gardens have both an economic function (food provision) and a social function (provision of social contact), irrespective of the geographical region in which they are situated. Often urban gardening projects are also political battles around the power of disposition over (urban public) space. ${ }^{5}$ Existing German studies fail to capture the complexity of this kind of urban gardening. They are either based on the perspective of urban agriculture (Lohrberg, 2001) or concentrate on the specific forms of green interim uses (BBR, 2004; cet-0 and studio urban catalyst, 2004; Eißner and Heydenreich, 2004).

For the purpose of my research, and in contrast to other forms of urban gardening, the collective and public character of community gardens is essential for their definition. Public character in most of
2. The financial situation is undoubtedly severe: Whereas in 1993 the different boroughs altogether had about $€ 60$ million at their disposal for the maintenance of public parks, in 2003 it was only €20 million. In 2000 the boroughs received on average only $39 \%$ of what they needed for the maintenance of standards (EA.UE, 2000: $25)$. For detailed information on diverse strategies in Berlin based on an analysis of official documents and reports, websites, newspaper articles, etc. see Rosol (2006: 83-118).

3. This new leitbild of the state is also expressed in urban policies, e.g. the introduction of new instruments of urban renewal like the programmes Soziale Stadt -Social City and Quartiersmanagement- Neighbourhood Management (see Silver et al., this issue; for a German critique, see Mayer, 2002; Krummacher et al., 2003).

4 . The case study is based on 44 semi-structured in-depth interviews and another 24 shorter interviews — some of them as group interviews - with community gardeners from 14 garden projects $(\mathrm{N}=26)$ and support organizations $(\mathrm{N}=12)$, local politicians and administrators $(\mathrm{N}=16)$, academics $(\mathrm{N}=6)$ and environmental organizations $(\mathrm{N}=8)$ conducted in 200304 and analysed with MaxQDA qualitative data analysis software. Further sources are participatory observation and analysis of secondary literature, media coverage and policy papers (for detailed information on methods see Rosol, 2006).

5. This is especially well documented for New York City (Schmelzkopf, 1995; 2002; Staeheli et al., 2002; Hassell, 2005; for another example see e.g. Lebuhn, 2008). Here the guerilla gardening movement stands out, which became famous in New York City in the 1970s (Meyer-Renschhausen, 2004; Reynolds, 2008). 
the studied cases also means full public access anytime. Although some of the gardens are only temporarily open to the general public, they can still fulfil important social or other functions that are relevant for a broader group of people or for the whole neighbourhood. In contrast to North American community gardens (Baker, 2004; Meyer-Renschhausen, 2004; Saldivar-Tanaka and Krasny, 2004) though, the Berlin gardens mostly do not serve productive functions. Flowers and shrubs are more commonly planted, and vegetables are planted for demonstration purposes, not as agricultural crops. Most gardens have collective areas as well as individual beds. The community garden groups are organized in different ways, ranging from loose groups to formally registered associations. The groups get funding from different sources: member fees and member donations, donations from outside or prize money. Most of them get public funding as well, sometimes only for the creation of the gardens, sometimes also for maintenance costs. With the following four examples of Berlin community gardens, I aim to identify the changing circumstances for involved community garden activists by comparing the only two surviving community gardening projects from the early 1980s and two newer gardens created around the year 2000. Particular attention will be paid to creation, aims, and the role of the local state and thus to the following two questions: who started the garden project and what were their aims in doing so?

\section{Lichtenrader Volkspark}

The oldest example is from 1977, when an informal garden was established on land that was earmarked as a construction site. The tenants of the adjacent large-scale housing development got together with professional community workers of the local church and a local citizens' action committee, Bürgerinitiative Lichtenrade Ost, to protest against the further density that the construction of more high-rises in an already very dense housing estate would cause, and they lobbied for a park instead. The neighbourhood already severely lacked open public space and - although situated at the margins of West Berlin - there was no access to the surrounding rural areas because of the Berlin Wall. More apartment housingwould only increase this imbalance. The protest initiatives did not stop at fighting development, but proposed the creation of a public park that would be in care of the community. In 1981, the activists founded the association Lichtenrader Volkspark e.V. After symbolic squatting on the land, planting shrubs and trees for publicity, neighbourhood parties, public relationswork and endless negotiations with local councillors, a contract for a small part of the landwas agreed with the borough in 1984. Not until 1989 was the use of the whole plot as a park completely legalized. It is the largest - 4.5 hectares - of the projects I studied and the one which most resembles a typical public park in appearance. Unlike common public parks however, its funding is mainly based on membership fees, donations and voluntary work.

6. There is limited data available on other and failing examples of older gardens, thus no representative sample can be provided. Although the possibility of earlier non-surviving state-organized gardens cannot be entirely eliminated, it is very unlikely given the all-embracing role of the state in the 1970s and 1980s and its unwillingness to engage self-help groups (see literature review above). Except on some rare occasions - when the city financed specific projects (such as a community composter) or when the association won an "environmental prize" and a prize for social engagement from the borough of Berlin-Tempelhof - there has been no public funding. The park is situated on public property and the Association leases the land - at no cost - from the borough under the condition that it is fully accessible to the public at all times. 


\section{Kinderbauernhof Mauerplatz Kreuzberg}

This urban farm for children in Berlin-Kreuzberg came into existence as a result of squatting on derelict land right beside the BerlinWall in 1981. A registered association (Kinderbauernhof Mauerplatz e.V.) was founded in the same year. In contrast to other projects examined in this article, the urban farm is not solely about gardening, but also includes the care of domestic animals (horses, donkeys, ducks, etc.). The idea to create an urban farm for children in Kreuzberg dates back to circa 1979. Organized mainly by single mothers, the aim was to create an educationally supervised green space for small children in this densely built-up inner-city borough. At the same time, the project was part of a broader social movement of squatters and other social activists against the predominant urban renewal policies of that time (Kahlschlagsanierung, the clearence of old tenements to make way for new high-rise buildings). With the founding of the Kinderbauernhof (children's farm) the group could criticize these policies as well as demonstrate alternative ways of creating a city. Members of the group have been actively engaged not only in environmental and educational topics, but also in local politics in general. One of the founders became a borough council member and actively influenced the local democratic system. The project has been an integral part of the neighbourhood for over 25 years. Although mainly organized by alternative and left-wing oriented white Germans, the users of the site reflect the diversity of the neighbourhood. One of the people involved in the project describes the involvement of the neighbourhood as follows:

It was part of the autonomous scene. Or at least it was referred to as such, although the social mix has been broader since the beginnings. How this project emerged was very much linked to the squatters' movement. But already in 1984, when I joined the group, therewas a larger social mix. There were seniors from the neighbourhood. And people from churches and Turkish neighbours... According to my experience there aren't many places where German and Turkish neighbours are in such close contact [as here] (interview with gardener, 19/2003).

The plot of about one hectare in size remained a squat for 20 years until in 2001 -after a long battle with the borough's politicians and administration - the association obtained a contract for over five years from the borough of Friedrichshain-Kreuzberg. During this long period of 20 years, the Kinderbauernhof remained highly contested, because the project evolved from the resistance against a misguided urban development policy and in direct confrontation with urban planners and local politics.

\section{Kids' Garden Neukölln}

The Kids' Garden (its name in German) is one of the newer projects. The concept of the Kids' Garden was first mooted in 1998. Soon a registered association (Grün für Kinder e.V.-Green Spaces for Children) was formed, and in 1999 it opened the garden. It is located in an area of urban renewal in the borough of Neukölln. The garden is for interim use only, and established on public land for at least 10 years. After that period, and pending sufficient financing, a public kindergarten 
and a public path connecting two streets are planned for the $3,000 \mathrm{~m}^{2}$ plot.

The idea for the garden came from the formal neighbourhood representation body (Betroffenenvertretung) assigned as representatives in the urban renewal process, butwas mostly self-organized by 14 parents' initiatives, which run private childcare facilities (Kinderläden) in the area. Their aim was to create outdoor facilities for their children, and provide environmental education and exposure. Children in this dense inner-city borough should have the opportunity to experience nature, to grow their own plants and to develop creativity while playing with natural materials. The project has common areas, and also small plots reserved for the different children's groups. Here the children can grow flowers, fruits and vegetables. The garden is usually locked, and apart from public events, is only accessible for the children, their educators, parents and their parents' friends. It is estimated that the garden is used by 250 children and 100 adults.

Northern Neukölln, like Kreuzberg, is an ethnically diverse neighbourhood and inhabitants with a Turkish background form a large proportion of the population. It is also one of the poorest neighbourhoods in Berlin.?

The Kids' Garden nevertheless is mostly organized by white middle-class Germans, typical for private childcare groups in Germany. Migrant inhabitants can use the garden through some of the children's facilities, but are not represented in the association itself. ${ }^{8}$ The creation of the garden was basically self-organized, and the parents' association finances the operating costs. Planners within the framework of the "Neighbourhood Management" and the urban renewal institutions actively supported the creation of the garden. The municipality was involved in facilitating the contract, organized soil tests and paid for setup costs. The association hopes to continue to use the plot even after the first contract ends. This hope is not unrealistic because the restricted financial situation of the Berlin government means that further development on the sites is unlikely. This project stands out because of its restricted public usage, which raises issues of exclusion and privatization. It is the least public garden in my research. The existence of locked gates is justified by the parents association with reference to the specific needs of small children. In favour of the garden it also has to be acknowledged that its creation did not close public space, but instead opened up a former private plot for the use of children from the neighbourhood. It still remains an ambivalent example because it is a garden where committed parents (have to) organize collectively in order to create - exclusive- green outdoor spaces for their children because the local authority does not adequately provide publicly accessible open spaces.

\section{Neighbourhood Garden "Dolziger Straße" Friedrichshain}

This garden was opened in 2002 and is also situated in a designated urban renewal area (Sanierungsgebiet). It is a very dense inner-city neighbourhood dating back to the end of the nineteenth century. Regarding built structures and densities, it is a neighbourhood similar to the one mentioned above where the Kids' Garden Neukölln is situated. This garden is located in East Berlin in a less diverse neighbourhood 
than Kreuzberg or Neukölln. Unlike the other examples, this garden is located on the private land of a single owner. The empty plot - about $800 \mathrm{~m}^{2}$ in size - is a relic of World War II bombing. The initial idea for this project came from the neighbourhood representation (Betroffenenvertretung), along with the urban renewal administration of the borough and the assigned urban planning bureau Stattbau GmbH.

The starting point for the initiation of an interim use by the borough was the severe lack of open green spaces in the area and empty plots used as garbage dumps with no foreseeable development in the imminent future. The aims were to improve the appearance of the neglected site and to foster civic engagement. The process was initiated in 2000 and subsequently supported by urban planners. Through guided walks in the neighbourhood and participative planningworkshops, municipal staff provided the prerequisites for forming a group of neighbours who took on the responsibility for the lot. Municipal planners played a crucial role not only in initiating this kind of land use, but also in providing information and assistance and in funding the ongoing process. Nevertheless, only the gardening group makes decisions about what actually happens on these plots. The project is not free from conflict though: a group of about 12 neighbours wants the borough to buy the piece of land and guarantee its long-term use. Although the borough acknowledges the lack of open spaces, the aim of urban renewal for the plot is still the redevelopment of the site. The landowner can give notice as soon as a building permit is issued.

Despite having initiated the projects, the state representatives see the local authority's role in these initiatives as supportive rather than leading because: "this kind of initiative from above, from the administration, well, you can do that, but it does not correspond to our idea, actually. Basically that is the call for the state which, I think, is not appropriated anymore" (interviewwith borough planning staff, 13/2003). This project thus exemplifies the turn towards the 'enabling and activating' state as characterized above.

\section{The changing role of the local state}

Looking at only these four examples, one finds very different models of creating a community garden (see Table 1). We have seen a self-organized park, which was supported by professional community workers from the local church (Lichtenrader Volkspark). The urban farm for children is an example of a grassroots project, part of a broader social movement and developed in confrontation with urban planners. The newer Kids' Garden is also an autonomously organized project, but was developed in cooperation with urban planners. The last example - the neighbourhood garden in Friedrichshain - was initiated mainly by urban planners and supported by politicians. This suggests that the role and involvement of the local state has shifted over time, from antagonism towards a kind of self-determined land use, towards supporting or even initiating it. It also indicates a turn from community gardens as part of urban social movements towards community gardens as a form of voluntarism. 


\begin{tabular}{|c|c|c|c|c|}
\hline Name & Lichtenrader Volkspark & $\begin{array}{l}\text { Kinderbauernhof Mau- } \\
\text { erplatz Kreuzberg }\end{array}$ & Kids' Garden Neukölln & $\begin{array}{l}\text { Neighbourhood Gar- } \\
\text { den "Dolziger Straße" } \\
\text { Friedrichshain }\end{array}$ \\
\hline Founded & 1979 & 1981 & 1998 & 2002 \\
\hline Size & 4.5 hectares & $9.000 \mathrm{~m}^{2}$ & $3000 \mathrm{~m}^{2}$ & $818 \mathrm{~m}^{2}$ \\
\hline Established by & $\begin{array}{l}\text { Community organizer } \\
\text { and community pres- } \\
\text { sure group, local neigh- } \\
\text { bours }\end{array}$ & $\begin{array}{l}\text { Community pressure } \\
\text { group, squatter move- } \\
\text { ment, local neighbours }\end{array}$ & $\begin{array}{l}\text { Private parents' initia- } \\
\text { tives with support from } \\
\text { formal neighbourhood } \\
\text { representation }\end{array}$ & $\begin{array}{l}\text { By order of urban re- } \\
\text { newal administration } \\
\text { of the district, with } \\
\text { support from formal } \\
\text { neighbourhood repre- } \\
\text { sentation }\end{array}$ \\
\hline $\begin{array}{l}\text { Maintained and man- } \\
\text { aged by }\end{array}$ & $\begin{array}{l}\text { Tragerverein Lichten- } \\
\text { rader Volkspark e.V. } \\
\text { (formal dvic associa- } \\
\text { tion) }\end{array}$ & $\begin{array}{l}\text { Kirderbauernhof am } \\
\text { Mauerplatz e.v. (formal } \\
\text { dvic association) }\end{array}$ & $\begin{array}{l}\text { Grün für Kinder e.V. } \\
\text { (formal civic associa- } \\
\text { tion) }\end{array}$ & $\begin{array}{l}\text { Neighbourhood group } \\
\text { (informal association) }\end{array}$ \\
\hline Role of local state & $\begin{array}{l}\text { Opponent, later nego- } \\
\text { tiation partner }\end{array}$ & Opponent & Support cooperation & $\begin{array}{l}\text { Key role in initiation } \\
\text { and organisation, on- } \\
\text { going support (fund- } \\
\text { ing, information, assis- } \\
\text { tance) }\end{array}$ \\
\hline $\begin{array}{l}\text { Funding of operating } \\
\text { costs }\end{array}$ & $\begin{array}{l}\text { Mainly membership } \\
\text { fees and private dona- } \\
\text { tion }\end{array}$ & $\begin{array}{l}\text { Mainly membership } \\
\text { fees and private dona- } \\
\text { tion in part public pro- } \\
\text { ject funding }\end{array}$ & $\begin{array}{l}\text { Mainly membership } \\
\text { fees }\end{array}$ & Mainly public \\
\hline Land ownership & $\begin{array}{l}\text { Public (purchased } \\
\text { 1986) }\end{array}$ & Public & $\begin{array}{l}\text { Public (purchased } \\
\text { 1997) }\end{array}$ & Private \\
\hline Legal status & $\begin{array}{l}\text { Long-term lease con- } \\
\text { tract since } 1989\end{array}$ & $\begin{array}{l}\text { Temporary contract } \\
\text { since } 2001 \text { (to be re- } \\
\text { newed periodically ) }\end{array}$ & $\begin{array}{l}\text { Long -term lease con- } \\
\text { tract since } 1998\end{array}$ & $\begin{array}{l}\text { Temporary contract } \\
\text { since } 2002 \text { (to be re- } \\
\text { newed annualy) }\end{array}$ \\
\hline Foreseen (other?) uses & $\begin{array}{l}\text { Dedicated public green } \\
\text { space in Berlin land } \\
\text { use plan }\end{array}$ & $\begin{array}{l}\text { Kindergarten (aban- } \\
\text { doned), School, hous- } \\
\text { ing (no sped fied uses) }\end{array}$ & $\begin{array}{l}\text { Public green way and } \\
\text { kindergarten }\end{array}$ & $\begin{array}{l}\text { Mixed building de- } \\
\text { velopment by private } \\
\text { inves or }\end{array}$ \\
\hline Public access & $\begin{array}{l}\text { Possible anytime by } \\
\text { anyone }\end{array}$ & $\begin{array}{l}\text { Posslble anytime by } \\
\text { anyone }\end{array}$ & Restricted & $\begin{array}{l}\text { Possible anytime by } \\
\text { anyone }\end{array}$ \\
\hline
\end{tabular}

Table 1: Analysis of case study gardens.
How does the local state justify its present engagement? In the interviews I conducted with local politicians and urban planners working in the administration, three reasons were given for their support of volunteer-run gardening projects in the public sphere: Firstly —and not surprisingly - their support and call for voluntary engagement for public spaces results from severe cuts in public spending for open green spaces in Berlin. Voluntarism is seen as a means of dealing with this problem. Secondly, they hope for an improved appearance of the neighbourhood. It should look clean, pretty and secure, and voluntarywork by neighbours, their presence in the lots and the associated social control are seen as an effective tool to ensure this. One background for this new interest in the public realm is that the traditional task of providing affordable housing through urban renewal has decreased dramatically in Germany and is no longer considered a public responsibility (Holm, 2006). Policymakers' interest in rearranging the public realm according to middle-class values is a common trend worldwide, closely attached to gentrification and "urban renaissance" (Imrie and Raco, 2003; Porter and Shaw, 2009). Finally, the planners and state administrators argue politically for a stimulation of civic engagement, community responsibility and social capital in order to "stabilize the neighbourhood" (interview with borough staff, 13/2003). These aims are clearly expressed in the following quote:

The financial situation is really always the fulcrum and pivot. That's unfortunate to a certain extent. But, on the other hand there is also... this 
whole approach, how can you strengthen again an orientation towards the common good, towards the community. The fact that one should not only count on the state, but also, as far as possible, take care of something with one's own resources (interview with borough councillor, 45/2004).

This quote says clearly that the starting point of the new interest in volunteering is the lack of funding for the parks maintenance. At the same time the councillor alludes to "the common good" and demands more input by the "community", including taking on responsibility and providing resources as a community member. In this respect, this quote connects the two trends of neoliberalizing cities - the lack of funding for public infrastructures and the responsibilization of the "the community" (Rose, 1996; Jessop, 2002) — in an exemplary way.

\section{Conclusion}

The first question raised in this article was: to what extent can the changing conditions for participation be analysed looking at the changing role of state and non-state actors in urban governance? In order to answer this question, I looked at a specific example of urban green spaces that combines participatory and grassroots approaches, civic engagement and local protest. In line with theoretical observations, my empirical case study shows a new acceptance by the local state of collectively run urban green spaces. Whereas in the early 1980s citizen groups who wanted to green public spaces were stymied by the local state and had to fight for their right to influence their environment, today such projects are actively encouraged and supported by the city administration and politicians. How can this be explained? Part of it is certainly the success of grassroots activism and lobbying, of social struggle and active participation in local politics. Pioneer projects certainly eased things for the future generation of gardens and increased their acceptance. However, in this article I want to draw attention to the fact that the conditions that brought the newer gardens into existence are also an expression of the 'actually existing neoliberalization of cities, where the local state withdraws from its welfarist functions and civic engagement is seen as a cheap solution. The newer gardens exemplify the turn towards the "enabling and activating" state (Neighbourhood Garden 'Dolziger Straße' Friedrichshain) or the increasing responsibility of private actors for the provision of services (Kids' Garden). Nevertheless, the specific situation of Berlin also has to be taken into account, since restructuring processes are path-dependent and uneven. That means, although we can detect a general trend of neoliberalization in many cities worldwide, there are still inherited regulatory landscapes, national and municipal legislation, the specific social and economic situation of any given city, and specific circumstances like the amount of land owned by that city, which have to be taken into account. In the specific case presented here, many of the studied gardens on public land became possible only because of the appalling budgetary situation of the City of Berlin. Because the City was not willing or able to fund the foreseen collective infrastructure, land fell vacant. This opened up a possibility for interim uses like gardens. As a result however, the gardens will have to go as soon as the eventual use - like a kindergarten in case of the Kids' Garden- has obtained financing and can finally be realized. Gardens on private land, on the other hand, became pos- 
sible due to the specific situation of the real estate market in Berlin. The plots are empty because development is currently not profitable enough. In this case too these gardens have no long-term guarantee. In their contract, Friedrichshain's community gardeners had to agree to clear the land as soon as private investors show interest and, subsequently, a building permit is issued.

Insofar as this new acceptance of community green spaces is not a general appreciation of independently run green spaces and the support is only for temporary uses of urban brownfield sites, the tenure of community gardens in Berlin is fragile. The current arrangements are only valid until "big investors" come back into the city. Comments by Berlin officials and their insistence on the term "interim use" suggest that gardens are seen mostly as a stop-gap measure or a second-best option in times of slow real estate development. This is also related to the fact that the gardens meet certain aspirations of the local state, but do not tackle the real problem: the maintenance of larger existing parks. Even if only temporary, however, support from urban planners stemming from limited financial resources and a reorientation towards community responsibility and volunteering has changed the possible fields of action of community greening projects. Therefore I posed a second series of questions: what chances and problems does the new acceptance or even support of self-organized use of open space by the local state imply? Does it open up new opportunities? Or is self-help the only chance for deprived urban areas to get any public green space? This is always an empirical question, which thus cannot be answered in general. The study of the history of Berlin community gardening projects shows that the new situation leads to a complex outcome providing both opportunities and problems. The acknowledgement and support of community gardens, on the one hand, make possible the emergence of new spaces with other uses, other designs and styles, with or without regulations. Also the gardens initiated and supported by the local state open up former private space and offer self-determined space, decentralized and non-bureaucratic solutions. These spaces are appreciated and used by local residents. In some cases, the gardens function as an important social meeting point for a neighbourhood. They have the potential for raising political awareness, which goes beyond the actual garden. And even if they were originally thought of as being only for interim uses, there is a good chance of securing them after they have successfully operated for a while and won enough support from residents and others. ${ }^{9}$

On the other hand, community services provision serves as a neoliberal strategy because it can support the outsourcing of responsibility for public infrastructures like parks. Both the reasons given by planners and other City officials for their support as well as some contradictions within the gardens themselves point into that direction. In that regard the example of Kids Garden' is especially ambiguous. In this way, self-help is legitimated as compensation for cuts in funding public infrastructure maintenance and for the devastating effects of neoliberal restructuring. And even if the state still provides some funding for ment gardens in Berlin, which have been in existence for more than 100 years now (Gröning, 2000).

10. The money the borough provides for the garden in Friedrichshain for example (about €3,000 annually for maintenance plus contractual payment of the planning bureau) would be a drop in the ocean if it were directly running a public park. the gardening groups, their volunteering is basically used as cheap labour. ${ }^{10}$ More generally, the rising status of private actors in urban green space governance opens up questions of democratic provision and control of public infrastructures including urban public green space.

In sum, although the support of community garden projects cannot be classified exclusively as a neoliberal strategy, this new acceptance of 
community groups is very ambiguous: it is both functional and fragile, given that only temporary uses are encouraged. Gardening groups have to acknowledge these new circumstances. They can use this support to promote their own cause, but have to be aware of the local state's differing interests.

If we look at the historical changes of community gardening in Berlin we can find a shift from community gardening with strong connections to urban social movements towards community gardening as a form of voluntarism or the provision of social services. This of course has important implications for the question of participation. The changes discussed earlier of participation in the context of neoliberalizing cities are relevant here: the withdrawal of funding from public infrastructures and the resulting outsourcing and privatization of state services as well as the responsibilization of citizens for the provision of services are especially obvious in the green space governance of Berlin today. Also the increasing competition for public funding between different groups can be detected, although also newfunding sources are opening up. The discourse of collaboration and participation as co-optation (see section on "Citizen Participation in Neoliberalizing Cities") are less important in the analysed cases.

From another perspective we can see that different strategies and phases which are often shown as contrary (Silver et al., this issue) are all part of the participatory experiences described here. Although generally this article claims that earlier community gardening projects were developed from a more oppositional stance using confrontational strategies, these projects also used deliberation and negotiations - especially around land tenure- to secure their goals. Equally the newer projects, although created in a deliberative manner and with support from the local authority, have to push for their interests: the garden "Dolziger Straße" in Friedrichshain for a long-term guarantee of their project, the Kids' Garden against the borough's efforts to create a public greenway and kindergarten. The main difference consists therefore less in the strategies used than in the view of the state and of the projects themselves.

This means that in the general discussion on urban contention and deliberation this article pleads for the importance of the historical and geographical specifity - and for an analytical rather than a normative approach towards questions of participation-. In this we are able to see how participatory experiences change with changes in society in general, and how this must lead to very different theoretical and political evaluations of the projects themselves. 
ARMSTRONG, Donna. A survey of community gardens in upstate New York: Implications for health promotion and community development. Health $\mathcal{E}^{\circ}$ Place, 2000, vol. 6, p. 319-327.

AMIN, A. Local community on trial. Economy and Society, 2005, 34.4, p. 612-33.

AYLETT, A. Conflict, Collaboration, and Climate Change: Participatory Democracy and Urban Environmental Struggles in Durban, South Africa. International Journal of Urban and Regional Research, 2010, 34.3, p. 478-495.

BAKER, L. Tending cultural landscapes and food citizenship in Toronto's community gardens. Geographical Review, 2004, 94.3, p. 305-25.

BBR (Bundesamt für Bauwesen und Raumordnung) Zwischennutzung und neue Freiflächen. Städtische Lebensräume der Zukunft. Projekt des Forschungsprogramms der 'Projektplanung Aufbau Ost' [Temporary use and new open spaces. Urban living space for the future. Project of the research program of 'Project Planning Development East']. Berlin: BBR, 2004.

BECHER, D. Bringing conflict and representation back in: intermediation and collective action as participatory institutions. International Journal of Urban and Regional Research, 2010, 34.3, p. 496-511.

BODENSCHATZ, H., V. HEISE and J. KORFMACHER. Schluß mit der Zerstörung? Stadterneuerung und städtische Opposition in West-Berlin, Amsterdam und London [End destruction? Urban renewal and urban opposition inWest Berlin, Amsterdam and London]. Gießen: Anabas, 1983.

BONDI, L. and N. LAURIE. Working the spaces of neoliberalism: activism, professionalisation and incorporation. Introduction. Antipode, 2005, 37.3, p. 394-401.

BRAND, K-W., D. BÜSSER and D. RUCHT. Aufbruch in eine andere Gesellschaft. Neue soziale Bewegungen in der Bundesrepublik [Departure for another society. New social movements in the Federal Republic]. Frankfurt/ Main: Campus, 1986.

BRENNER, N. and N. THEODORE. Cities and the geographies of 'actually existing neoliberalism'. Antipode, 2002a, 34.3, p. 349-379.

BRENNER, N. and N. THEODORE (eds.) Spaces of neoliberalism: urban restructuring in Western Europe and North America. Oxford and Boston: Blackwell, 2002b.

BRENNER, N. and N. THEODORE. Neoliberalism and the urban condition. City, 2005, 9.1, p. 101-107.

CET-0 and STUDIO URBAN CATALYST. Raumpioniere Berlin [Berlin space pioneers]. Berlin: Studie i.A. der Senatsverwaltung für Stadtentwicklung, Abtl. I Stadt- und Freiraumplanung, 2004.

EA.UE (ed.) Kein Geld für Stadtgrün? Finanzierungs- und Managementstrategien für Grünflächen in Berlin und polnischen Städten (Konferenzbericht) [No money for public greenery? Financial and management strategies for green spaces in Berlin and Polish cities. Conference proceedings]. Berlin: Europäische Akademie für städtische Umwelt EA.UE, 2000.

EISSNER, C. and S. HEYDENREICH (eds.) Baulücke? Zwischennutzen! Ein Ratgeber für denWeg von der Brachfläche zur Stadtoase [Vacant lot? Temporary use! A guide for the transformation of a vacant lot into an urban oasis]. Bonn: Stiftung Mitarbeit, Arbeitshilfen Nr. 32, Verlag Stiftung Mitarbeit, 2004.

ELWOOD, S. Neighborhood revitalization through 'collaboration': assessing the implications of neoliberal urban policy at the grassroots. GeoJournal, 2002, 58.2/3, p. 121-130.

ELWOOD, S. Partnerships and participation: reconfiguring urban governance in different state contexts. Urban Geography, 2004, 25.8, p. 755-770.

ESSER, J. Konzeption und Kritik des kooperativen Staates [Concept and critique of the cooperative state]. In C. GÖRG and R. ROTH (eds.), Kein Staat zu machen. Zur Kritik der Sozialwissenschaften [Nothing to write home about. A critique of the social science]. Münster: Westfälisches Dampfboot, 1998.

ETZIONI, A. The spirit of community. Rights, responsibilities, and the communitarian agenda. New York: Crown Publishers, 1993.

EVERS, A. Bürgergesellschaft und soziales Kapital. Die politische Leerstelle im Konzept Robert Putnams [Civic society and social capital. The political void in the concept of Robert Putnam]. In M. HAUS (ed.) Bürgergesellschaft, soziales Kapital und lokale Politik. Theoretische Analysen und empirische Befunde [Civic society, social capital and local politics. Theoretical analysis and empirical findings], Opladen: Stadtforschung aktuell Band 86. Leske+Budrich, 2002.

GEDDES, M. Partnership and the limits to local governance in England: institutionalist analysis and neoliberalism. International Journal of Urban and Regional Research, 2006, 30.1, p. 76-97.

GHOSE, R. The complexities of citizen participation through collaborative governance. Space and Polity, 2005, 9.1, p. 61-75.

GRÖNING, G. Kampfesmutige Laubenpieper. Kleingärten und Politik in Berlin zwischen 1985 und 1995 [Rebellious allotment gardeners. Allotment gardens and politics in Berlin between 1985 and 1995]. In A. HOLL and E. MEYER-RENSCHHAU- 
SEN (eds.), Die Wiederkehr der Gärten [The return of the gardens], Innsbruck: Studien-Verlag, 2000.

HAIDLE, I. and C. ARNDT. Urbane Gärten in Buenos Aires [Urban gardens in Buenos Aires]. Berlin: ISR Diskussionsbeiträge Heft 59. Institut für Stadt- und Regionalplanung, Technische Universität Berlin, 2007.

HALL, T. and P. HUBBARD (eds.) The entrepreneurial city: geographies of politics, regime, and representation. New York: Wiley-Academy, 1998.

HARVEY, D. From managerialism to entrepreneurialism: the transformation in urban governance in late capitalism. Geografiska Annaler Series, 1989, B 71.1, p. 3-17.

HASSELL, M. v. Community gardens in NewYork City: place, community and individuality. In P. BARTLETT (ed.), Urban Place, Cambridge, MA: MIT Press, 2005.

HERBERT, S. The trapdoor of community. Annals of the Association of American Geographers, 2005, 95.4, p. 850-65.

HIRSCH, J. Der Sicherheitsstaat. Das 'Modell Deutschland', seine Krise und die neuen sozialen Bewegungen [The security state. The 'German model', its crisis and new social movements]. Frankfurt/Main: Europäische Verlagsanstalt, 1980.

HIRSCH, J. Sozialstaatskrise und das sozialdemokratische Dilemma [Crisis of the social state and the social democratic dilemma]. Widersprüche, 1982, 2.2, $51 \mathrm{ff}$.

HOLM, A. Urban renewal and the end of social housing. The roll out of neoliberalism in East Berlin's Prenzlauer Berg. Social Justice, 2006, 33.3, p. 114128.

IMRIE, R. and M. RACO (eds.) Urban renaissance? New Labour, community and urban policy. Bristol: Policy Press, 2003.

JESSOP, B. Liberalism, neoliberalism, and urban governance: a state-theoretical perspective. In $\mathrm{N}$. BRENNER and N. THEODORE (eds.), Spaces of neoliberalism: urban restructuring in Western Europe and North America. Oxford: Blackwell, 2002.

KRÄTKE, S. City of talents? Berlin's regional economy, socio-spatial fabric and 'worst practice' urban governance. International Journal of Urban and Regional Research, 2004, 28.3, p. 511-29.

KRÄTKE, S. and F. SCHMOLL. Der lokale Staat —_Ausführungsorgan' oder 'Gegenmacht'” [The local state- executive or countervailing power]. PROKLA. Zeitschrift für kritische Sozialwissenschaft, 1987, 17.3, p. 30-72.

KRUG-GBUR, V. and L. PREISLER-HOLL. Schritt für Schritt aus der 'grünen' Krise [Step by step out of the 'green' crisis]. Stadt und Raum, 2/2004, 94-97.

KRUMMACHER, M., R. KULBACH, V. WALTZ and N. WOHLFAHRT. Soziale Stadt, Sozialraumentwicklung, Quartiersmanagement. Herausforderungen für Politik, Raumplanung und Soziale Arbeit [Social city, social spa- ce development, neighbourhood management. Challenges for polity, spatial planning and social work]. Opladen: VS Verlag, 2003.

LEBUHN, H. Stadt in Bewegung. Mikrokonflikte um den öfentlichen Raum in Berlin und Los Angeles [City in movement. Micro conflicts around public space in Berlin and Los Angeles]. Münster: Westfälisches Dampfboot, 2008.

LINDENBERG, M. Aufgeklärte Herrschaft im aktivierenden Staat. Anmerkungen zu den Thesen der Hamburger Sozialsenatorin 'zur Zukunft der sozialen Arbeit in Hamburg' [Enlightened rule within the activation state. Comments on the thesis of the Hamburg social senator 'for the future of social work in Hamburg']. Widersprüche, 2002, 22.84, p. 77-87.

LOHRBERG, F. Stadtnahe Landwirtschaft in der Stadtund Freiraumplanung [Urban agriculture as a subject of urban and open space planning]. PhD dissertation, Fakultät Architektur und Stadtplanung, Institut für Landschaftsplanung und Ökologie. Stuttgart: Universität Stuttgart, 2001.

MACKINNON, D. Managerialism, governmentality and the state: a neo-Foucauldian approach to local economic governance. Political Geography, 2000, 19.3, p. 293-314.

MATHÉY, K. (ed.) Urban agriculture (special issue). Trialog-Zeitschrift für das Planen und Bauen in der Dritten Welt [Trialog - A Journal for Planning and Building in the Third World], 2000, 65.

MAYER, M. Post-Fordist city politics. In A. AMIN (ed.), Post-Fordism. A reader. Oxford: Blackwell, 1994.

MAYER, M. Soziales Kapital und Stadtentwicklungspolitik - ein ambivalenter Diskurs [Social capital and urban development politics - an ambivalent discourse]. In M. HAUS (ed.), Bürgergesellschaft, soziales Kapital und lokale Politik. Theoretische Analysen und empirische Befunde. Stadtforschung aktuell Band 86. Opladen: Leske+Budrich, 2002.

Mayer, M. The onward sweep of social capital: causes and consequences for understanding cities, communities and urban movements. International Journal of Urban and Regional Research, 2003, 27.1, p. 110-132.

Meissle, K. Brachland in Berlin. Zur Bedeutung transitorischer Räume in der Stadt [Vacant land in Berlin. The salience of transitoric space in the city]. Stadt und Grün 4/1998, p. 247-251.

MEYER-RENSCHHAUSEN, E. Unter dem Müll der Acker [Below the waste the field]. Community Gardens in New York City. Königstein/Taunus: Konzepte / Materialien Band 2 Ulrike Helmer Verlag, 2004.

MEYER-RENSCHHAUSEN, E. (ed.) Die Gärten der Frauen -Zur sozialen Bedeutung von Kleinstlandwirtschaft in Stadt und Land weltweit [The gardens of women - the social salience of micro agriculture in urban and rural areas in the world]. Herbolzheim: Centaurus-Verlag, 2002. 
PAINTER, J. and M. GOODWIN. Local governance after Fordism: a regulationist perspective. In G. STOKER (ed.), The new politics of British local government. Basingstoke: Macmillan, 2000.

PECK, J. and A. TICKELL. Neoliberalizing space. Antipode, 2002, 34.3, p. 380-404.

Porter, L. and K. SHAW (eds.) Whose urban renaissance? An international comparison of urba $n$ regeneration strategies. London: Routledge, 2009.

REYNOLDS, R. On guerrilla gardening: a handbook for gardening without boundaries. London: Bloomsbury, 2008.

ROSE, N. The death of the social? Refiguring the territory of government. Economy and Society, 1996, 25.3, p. 327-356.

ROSOL, M. Gemeinschaftsgärten in Berlin. Eine qualitative Untersuchung zu Potenzialen und Risiken bürgerschaftlichen Engagements im Grünflächenbereich vor dem Hintergrund des Wandels von Staat und Planung [Community gardens in Berlin. A qualitative analysis concerning potentials and risks of civic engagement in the green sector against the background of changing statehood and spatial planning]. Berlin: Mensch-und-Buch-Verlag, 2006.

ROTH, R. Lokale Demokratie 'von unten'. Bürgerinitiativen, städtischer Protest, Bürgerbewegungen und neue soziale Bewegungen in der Kommunalpolitik [Local democracy 'from below'. Citizens' action committees, urban protest, citizen movements and new social movements in municipal politics]. In R. ROTH and H. WOLLMANN (eds.), Котmunale Politik. Politisches Handeln in den Gemeinden. Opladen: Leske+Budrich, 1994.

ROTH, R. Die dunklen Seiten der Zivilgesellschaft —Grenzen einer zivilgesellschaftlichen Fundierung von Demokratie [The dark sides of civil society- li- mits of a civil society based democracy]. Forschungsjournal Neue Soziale Bewegungen, 2003, 16.2, p. 59-73.

RÜDDENKLAU, W. Störenfried [Troublemaker]. Berlin: Verlag BasisDruck, 1992.

SALDIVAR-TANAKA, L. and M.E. KRASNY. Culturing community development, neighborhood open space, and civic agriculture: the case of Latino community gardens in New York City. Agriculture and $\mathrm{Hu}$ man Values, 2004, 21.4, p. 399-412.

SCHMELZKOPF, K. Urban community gardens as contested space. Geographical Review, 1995, 85.3, p. 364-381.

SCHMELZKOPF, K. Incommensurability, land use, and the right to space: community gardens in New York City. Urban Geography, 2002, 23.4, p. 323-343.

SCHRÖDER, T. Der Park lebt nicht vom Staat allein [A park does not live on the state alone]. Topos 19/2000, p. 68-74.

SILVER, H., A. SCOTT and Y. KAZEPOV. Participation in urban contention and deliberation. International Journal of Urban and Regional Research, 2010, 34.3, p. 453-477.

STAEHELI, L.A., D. MITCHELL and K. GIBSON. Conflicting rights to the city in New York's community gardens. GeoJournal, 2002, 58.2/3, p. 197-205.

SWYNGEDOUW, E. Governance innovation and the citizen: the janus face of governance-beyond-thestate. Urban Studies, 2005, 42.11, p. 1991-2006.

THIEL, W. Selbsthilfe und 'informeller Sektor' auf der lokalen Ebene [Self-help and the 'informal sector' on the local scale]. In R. ROTH and H. WOLLMANN (eds.), Kommunale Politik. Politisches Handeln in den Gemeinden [Municipal politics. Political acting in municipalities], Opladen: Leske+Budrich, 1994.

ROSOL, Marit. Public Participation in Post-Fordist Urban Green Space Governance: The Case of Community Gardens in Berlin. Hábitat y Sociedad, 2014, nº 7, p. $15-30$.

$<$ www.habitatysociedad.us.es $>$

http://dx.doi.org/10.12795/HabitatySociedad.2014.i7.02 